\title{
Зенкор Ультра, КС для защиты моркови
}

\section{Н.И. Берназ, В.С. Голубович}

Приведены результаты исследований по оценке эффективности гербицидов на посевах моркови. Установлена оптимальная норма применения Зенкор Ультра, КС, его биологическая эффективность и безопасность использования. Зенкор Ультра, КС в оптимальной норме 0,5 л/га перспективен для применения на посевах моркови в фазу трех листьев, засоренных чувствительными к нему видами однолетних двудольных сорняков.

Ключевые слова: гербициды, норма, сорняки, морковь, эффективность.

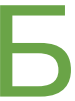
иологический потенциал продуктивности современных сортов и гибридов моркови реализуется примерно на 50\%. Один из определяющих факторов недобора урожая корнеплодов - высокая засоренность и низкая конкурентоспособность культуры к сорнякам в первую половину вегетационного периода.

Широкая производственная практика подтвердила высокую биологическую эффективность довсходового применения Стомп Профессионал, MKC, Рейсер, КЭ, при достаточном увлажнении в первые 7-10 дней после внесения, но при отсутствии дождей и поливов гербицидный эффект резко снижается, а также препараты недостаточно эффективны против поздно прорастающих сорняков (щирица запрокинутая, крестовник обыкновенный, осот огородный, паслен черный и др.), поэтому необходимо проводить дополнительную химическую обработку или ручную прополку

Сегодня в России из послевсходовых препаратов против двудольных сорняков разрешен только Гезагард, КС и его аналоги в фазу 1-2 настоящих листьев моркови [1]. Но гербицид слабо действует на щирицу запрокинутую, крестовник обыкновенный, паслен черный, галинсогу мелкоцветковую, которые чувствительны только в фазе всходов. В результате устойчивые к гербицидам виды сорняков накапливаются и становятся основными засорителями культуры. Избежать этих последствий можно используя различные по химическому составу и физиологическому действию препараты. В ряде зарубежных стран на посевах морко- ви широко применяют препараты на основе метрибузина [2, 3].

Цель работы - оценка биологической эффективности и избирательности послевсходового применения гербицида Зенкор Ультра, КС на посевах моркови.

Опыты проводились в 20162017 годах на экспериментальном поле ВНИИ овощеводства (Московская область, Раменский район).

Место проведения исследований входит во влажную зону со среднемноголетним количеством осадков 539 мм, из которых 320 мм выпадает в мае - сентябре. Почва опытного участка - аллювиальная, луговая, среднесуглинистая с содержанием гумуса 3,3\%. Кислотность почвенного раствора близка к нейтральной $\mathrm{pH} 6,2$.

Зенкор Ультра, КС испытывали в фазу трех листьев моркови на фоне обработки Реглон Супер, ВР 2,0 л/га за два дня до появления всходов культуры.

Зенкор Ультра, КС (метрибузин 600 г/л) - системный селективный гербицид фирмы «Байер Кроп Сайенс АГ», зарегистрирован в России для применения при выращивания картофеля, томатов, сои. Он поглощается корнями и проростками, а также легко проникает через листовую поверхность. У чувствительных к нему растений ингибирует транспорт электронов, участвующих в процессе фотосинтеза (фотосистема II). Препарат малотоксичен для человека и животных, малоопасен для пчел и насекомых. Однако при работе с ним необходимо соблюдать общие меры предосторожности.
На первой стадии борьбы с сорняками необходим правильный выбор предшественника для моркови, позволяющий искоренить многолетние сорняки. Для Нечерноземной зоны при выращивании моркови на гребневой поверхности одним из лучших предшественников является вико-овсяная смесь. Через месяц после ее уборки проводили опрыскивание Ураган Форте, ВР 4,0 л/га по отросшим многолетним и взошедшим однолетним сорнякам, а затем зяблевую вспашку во второй декаде сентября. После весенней культивации зяби, во второй декаде мая нарезали гребни фрезерным агрегатом, прикатывали и сеяли морковь сорта Берликум Роял в один и тот же день.

Опыты закладывали согласно «Методическим указаниям по регистрационным испытаниям гербицидов в сельском хозяйстве» [4]. Схема опыта включала 4 варианта: применение Зенкор Ультра, КС в трех нормах 0,3; 0,4 и 0,5 л/га и контроль (две ручные прополки). Площадь опытной делянки - 16,8 м², размещение систематическое, повторность четырехкратная. Гербициды вносили ручным ранцевым опрыскивателем «Solo 435» с нормой расхода рабочей жидкости 300 л/га.

Биологическую эффективность Зенкор Ультра, КС оценивали по снижению числа и массы сорняков относительно контроля через 30 дней после обработки и перед уборкой урожая. Урожай убирали вручную с каждой делянки отдельно.

Засоренность перед обработкой Реглон Супер, ВР была высокой (264 экз $\left./ \mathrm{M}^{2}\right)$. Через неделю после обработки гербицидом, погибало 98100\% мари белой, горца почечуйного, крестовника обыкновенного, галинсоги мелкоцветковой, находившихся в фазе семядоли - 3 листа.

Исходная засоренность перед обработкой Зенкор Ультра, КС составляла 196 шт/м². В видовом составе доминировал горец почечуйный (107 шт/м²). Реже встречались: марь белая, щирица запрокинутая, крестовник обыкновенный, паслен 


\begin{tabular}{|c|c|c|c|c|c|c|}
\hline \multirow{3}{*}{ Вариант } & \multirow{3}{*}{$\begin{array}{c}\text { Норма гербицида, } \\
\text { л/га }\end{array}$} & \multicolumn{4}{|c|}{ Снижение засоренности, \% к контролю } & \multirow{3}{*}{$\begin{array}{c}\text { Урожайность, } \\
\text { т/га }\end{array}$} \\
\hline & & \multicolumn{2}{|c|}{ через 30 дней после внесения } & \multicolumn{2}{|c|}{ перед уборкой урожая } & \\
\hline & & количество & мacca & количество & масса & \\
\hline Контроль* & - & 127 & 379 & 29 & 426 & 60,4 \\
\hline \multirow{3}{*}{ Зенкор Ультра, КС } & 0,3 & 69 & 64 & 29 & 23 & 63,9 \\
\hline & 0,4 & 87 & 86 & 37 & 29 & 62,6 \\
\hline & 0,5 & 95 & 97 & 42 & 36 & 67,1 \\
\hline $\mathrm{HCP}_{05}$ & & & & & & 5,6 \\
\hline
\end{tabular}

черный, галинсога мелкоцветковая и подмаренник цепкий. Большинство сорняков погибало на 5-7 дней после обработки, полный срок ожидания - 10-15 дней.

Через месяц после обработки, эффективность Зенкор Ультра, КС в норме 0,3 л/га (69\%) была наименьшей. От действия Зенкор Ультра, КС в норме 0,4 л/га погибало 87\% сорняков, а от 0,5 л/га - 95\% (табл.). При этом гибель горца почечуйного, мари белой, щирицы запрокинутой была абсолютной и 90-98\% галинсоги мелкоцветковой, крестовника обыкновенного. Высокую устойчивость к гербициду проявили подмаренник цепкий и паслен черный.

Лучший срок применения Зенкор Ультра, КС - период когда большинство сорняков находятся в ранних фазах развития (1-3 листа).

Остаточное почвенное действие Зенкор Ультра, КС сдерживало прорастание сорняков в течение 30-40 дней после обработки. К уборке урожая степень засоренности делянок обработанных гербицидами была на уровне контроля с двумя ручными прополками

Таким образом, эффективность применения Зенкора Ультра, КС

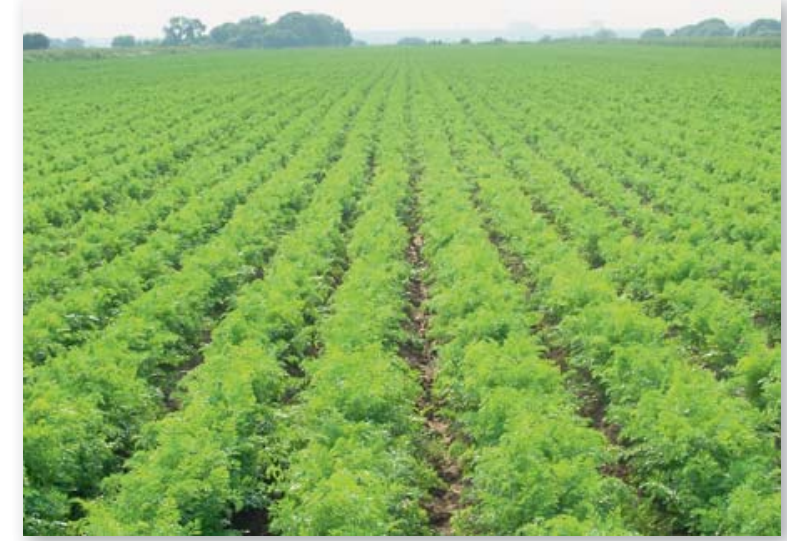

Участок, обработанный препаратом Зенкор Ультра, КС в норме 0,5 л/га в норме 0,5 л/га была максимальной и толерантной к растениям моркови.

Отрицательного влияния Зенкор Ультра, КС на рост и развитие моркови визуально не отмечали. Применение гербицида в испытуемых нормах не оказало существенного влияния на биохимический состав и качество корнеплодов. Анализами остаточных количеств метрибузина в корнеплодах моркови не обнаружено.

Для правильного выбора гербицидов в технологии эффективного применения важно учитывать видовой состав сорняков на конкретном поле и спектр действия гербицидов. На полях сильно засоренных семенами подмаренника цепкого и паслена черного гербицид Зенкор Ультра, KC целесообразно применять в комбинации с довсходовом внесением Команда, КЭ 0,2 л/га, к которому высокочувствительны вышеназванные сорняки [5].

Результаты испытаний свидетельствуют, что Зенкор Ультра, КС в оптимальной норме 0,5 л/га перспективен для применения на посевах моркови в фазу трех листьев, засоренных чувствительными к нему видами однолетних двудольных сорняков, после его регистрации на культуре.

\section{Библиографический список}

1.Справочникпестицидов и агрохимикатов, разрешенных к применению на территории Российской Федерации. M., 2019., 872 c.

2.Garcia Gonzales F., Segura Miranda A. Linuron, metolachlor y metribuzin control de maleza y residualidad en suelo y zanahoria (Daucus carota L.) en Chapingo, Mexico. (Оценка эффективности линурона, метолахлора и метрибузина в борьбе с сорняками на плантациях моркови в Чапинго, Мексика, содержание остаточных количеств гербицидов в почве и корнеплодах) // Rev. Chapingo. Ser. Protecc. Veget. 1994. Vol.1. No.4. Pp.113-116.

3.Jensen, K. J. N., Doohan D. J., Specht
E.G. Response of processing carrot to metribuzin on mineral soils in Nova Scotia (Оценка реакции на гербицид метрибузин некоторых сортов моркови, выращиваемой на переработку на минеральных почвах в провинции Новая Шотландия, Канада) // Plant Sc. 2004. Vol. 84. No.2. P.669 - 676.

4.Методические указания по регистрационным испытаниям гербицидов в сельском хозяйстве в части биологической эффективности. [Электронный ресурс]. URL: http://mcx.ru/upload/iblock/2d7/2d75ef71289b59 9078421696f2408ee0.pdf Дата обращения: 3.10.2019.

5.Берназ Н.И. Эффективность гербицидов в посевах моркови // Вестник овощевода. 2012. № 4. С. 25-26.

\section{Об авторах}

Берназ Николай Иванович, канд. с.-х. наук, в.н.с. отдела земледелия и агрохимии, Всероссийский научно-исследовательский институт овощеводства - филиал ФГБНУ «Федеральный научный центр овощеводства» (ВНИИО-филиал ФГБНУ ФНЦО).E-mail: vniioh@yandex.ru Голубович Виктор Сергеевич, канд. с.-х. наук, с.н.с. отдела технологий и инноваций, ВНИИО - филиал ФГБНУ ФНЦО.

E-mail:vniioh@yandex.ru

Zenkor Ultra, CS for carrots protection N.I. Bernaz, PhD, leading research fellow of department of agriculture and agrochemistry, All-Russian Research Institute of Vegetable Growing - the branch of FSBSI Federal Scientific Centre of

Vegetable Growing (ARRIVG - the branch of FSBSI FSVC). E-mail: vniioh@yandex.ru V.S. Golubovich, $P h D$, senior research fellow, department of technologies and innovations, ARRIVG - the branch of FSBSI FSVC.E-mail:vniioh@yandex.ru

Summary. The results of studies for assessment the effectiveness of herbicides on carrot crops are presented. The optimal norm of of Zencor UItra, KS application, its biological efficiency and safety of use are ascertained. Zencor Ultra, KS at an optimal rate of $0.5 \mathrm{I} / \mathrm{ha}$ is promising for use on carrots in the phase of three leaves clogged with sensitive species of annual dicotyledonous weeds.

Keywords: herbicides, norm, weeds, carrots, efficiency.

№10/2019 Картофель и овощи 